\title{
The relative importance of managerial competencies for predicting the perceived job performance of Broad-Based Black Economic Empowerment verification practitioners
}

\begin{tabular}{|c|c|}
\hline $\begin{array}{l}\text { Authors: } \\
\text { Barbara M. S } \\
\text { Raborale I.D. } \\
\text { Richard Chinc }\end{array}$ & $\begin{array}{l}\text { ate }^{1} \\
\text { ooe }^{2} \\
\text { mona }^{3}\end{array}$ \\
\hline $\begin{array}{l}\text { Affiliations: } \\
{ }^{1} \text { Department } \\
\text { Vaal Universi } \\
\text { South Africa }\end{array}$ & $\begin{array}{l}\text { Logistics, } \\
\text { of Technology, }\end{array}$ \\
\hline $\begin{array}{l}{ }^{2} \text { Department } \\
\text { Management } \\
\text { Johannesburg }\end{array}$ & $\begin{array}{l}\text { f Business } \\
\text { University of } \\
\text { South Africa }\end{array}$ \\
\hline $\begin{array}{l}{ }^{3} \text { Department } \\
\text { University of } \\
\text { South Africa }\end{array}$ & $\begin{array}{l}\text { ff Marketing, } \\
\text { Nitwatersrand, }\end{array}$ \\
\hline $\begin{array}{l}\text { Correspondir } \\
\text { David Pooe, } \\
\text { dpooe@uj.ac }\end{array}$ & $\begin{array}{l}\text { g author: } \\
\text { za }\end{array}$ \\
\hline $\begin{array}{l}\text { Dates: } \\
\text { Received: } 02 \\
\text { Accepted: } 08 \\
\text { Published: } 28\end{array}$ & $\begin{array}{l}\text { Mar. } 2015 \\
\text { Dec. } 2015 \\
\text { Apr. } 2016\end{array}$ \\
\hline $\begin{array}{l}\text { How to cite t } \\
\text { Seate, B.M., } \\
\text { Chinomona, } \\
\text { relative impo } \\
\text { managerial cc } \\
\text { predicting th } \\
\text { performance } \\
\text { Black Econom } \\
\text { Empowermer } \\
\text { practitioners. } \\
\text { Human Reso } \\
\text { Management } \\
\text { Menslikehulp } \\
\text { 14(1), a696. } \\
\text { org/10.4102/ } \\
\text { v14i1.696 }\end{array}$ & $\begin{array}{l}\text { is article: } \\
\text { ooe, R.I.D., \& } \\
\text { (2016). The } \\
\text { tance of } \\
\text { mpetencies for } \\
\text { perceived job } \\
\text { of Broad-Based } \\
\text { ic } \\
\text { t verification } \\
\text { SA Journal of } \\
\text { rce } \\
\text { SA Tydskrif vir } \\
\text { ronbestuur, } \\
\text { ttp://dx.doi. } \\
\text { ajhrm. }\end{array}$ \\
\hline $\begin{array}{l}\text { Copyright: } \\
\text { (C) 2016. The } \\
\text { Licensee: AO } \\
\text { is licensed un } \\
\text { Creative Com } \\
\text { Attribution Li }\end{array}$ & $\begin{array}{l}\text { uthors. } \\
\text { IS. This work } \\
\text { der the } \\
\text { nons } \\
\text { ense. }\end{array}$ \\
\hline Read online & \\
\hline 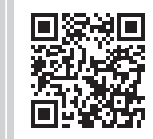 & $\begin{array}{l}\text { Scan this QR } \\
\text { code with your } \\
\text { smart phone or } \\
\text { mobile device } \\
\text { to read online. }\end{array}$ \\
\hline
\end{tabular}

Orientation: There is a need for the growing Broad-Based Black Economic Empowerment (B-BBEE) verification industry to assess competencies and determine skills gaps for the management of the verification practitioners' perceived job performance. Knowing which managerial competencies are important for different managerial functions is vital for developing and improving training and development programmes.

Research purpose: The purpose of this study was to determine the managerial capabilities that are required of the B-BBEE verification practitioners, in order to improve their perceived job performance.

Motivation for the study: The growing number of the B-BBEE verification practitioners calls for more focused training and development. Generating such a training and development programme demands empirical research into the relative importance of managerial competencies.

Research approach, design and method: A quantitative design using the survey approach was adopted. A questionnaire was administered to a stratified sample of 87 B-BBEE verification practitioners. Data were analysed using the Statistical Package for Social Sciences (version 22.0) and Smart Partial Least Squares software.

Main findings: The results of the correlation analysis revealed that there were strong and positive associations between technical skills, interpersonal skills, compliance to standards and ethics, managerial skills and perceived job performance. Results of the regression analysis showed that managerial skills, compliance to standards and ethics and interpersonal skills were statistically significant in predicting perceived job performance. However, technical skills were insignificant in predicting perceived job performance.

Practical/managerial implications: The study has shown that the B-BBEE verification industry, insofar as the technical skills of the practitioners are concerned, does have suitably qualified staff with the requisite educational qualifications. At the same time, from the present study the industry can now determine the priority skills.

Contribution: The study identified the needed skills as managerial skills, standards and ethics and interpersonal skills, in that order. The verification agencies will now be in a better position to know where they should focus their training and development.

\section{Introduction}

Organisations seem to have always battled to define their competency models and thus find the implementation of skills management problematic (Homer, 2001). The ability to assess competencies and determine skills gaps is critical as it enables organisations to manage individual and team performance better. Knowing which managerial competencies are important for different managerial functions is vital for developing and improving training and development programmes. As the scope of the modern organisation, which tends to be flatter and less hierarchical changes, competencies which managers considered important in the past may no longer be relevant today (Gentry, Harris, Baker, \& Leslie, 2007). The study investigated 87 BroadBased Black Economic Empowerment (B-BBEE) verification practitioners, all employed by verification agencies registered with the Association of BEE Verification Agencies. The aim of the study was to determine the relative importance of their managerial competencies in light of their 
influence on the perceived job performance. The article is organised as follows. The next section provides a brief background of the B-BBEE landscape, followed by a review of literature in the areas of managerial competencies and hypotheses development. This is followed by a section on the research methodology and the results. Finally, the article reflects on the limitations of the study and the study's implications and concludes with recommendations for future research direction.

\section{Background}

Through the B-BBEE legislative framework, it has become imperative in South Africa for a company to have an acceptable level of the B-BBEE status if it is to conduct business with government or its agencies (Ernest \& Young, 2013). The B-BBEE legislative framework aims to restructure the economy with a view to empower those who had been historically marginalised by apartheid and its legacy (Department of Trade and Industry [DTI], 2007; Levin, 2011; Rubushe, 2009). From its inception, the B-BBEE policy framework has not been without challenges. For example, in 2007 it became necessary to adopt and implement the Codes of Good Practice in order to deal with some challenges relating to the implementation of the BEE policy, including the lack of uniform framework for the recognition and measurement of BEE, extensive delays in BEE implementation because of differences in interpretation, lack of underlying economic substance to many BEE transactions and fronting due to lack of implementation guidelines (DTI, 2007). In the meantime, there were rating agencies that assisted companies develop their own scorecards reflecting the companies' level of B-BBEE compliance.

The Codes of Good Practice (Codes) introduced the B-BBEE Scorecard, which measures the degree of compliance to B-BBEE (DTI, 2007). This process would result in the issue of a certificate indicating a company's degree of compliance to B-BEEE, thereby giving a company a competitive edge in bidding for any kind of business with government or its agencies (Pooe, 2013). No sooner had the Codes been adopted, than some difficulties became evident in the implementation thereof. Lack or absence of common standards and criteria for assessing the B-BBEE status emerged as a major problem (Gomez \& Premdas, 2013). In order to overcome this problem, the DTI appointed the accreditation body, South African National Accreditation System to develop a set of accreditation criteria by which would be verification agencies could be assessed (DTI, 2007).

The role of a verification agency is to audit the scorecard with a view to ensure the factual correctness of the information provided to the verification agency (EconoBEE, 2009). Following the release of the first draft of the Codes in 2004, the number of verification agencies increased rapidly (Business Report, 2008), thus necessitating some form of regulation. To this end, in July 2008 the government published the Verification Manual for the creation of universal, transparent and coherent standards applicable in the verification industry. The aim of the manual was to set acceptable minimum standards and ethical codes of conduct underpinning the responsibilities of verification agencies to perform verification and reporting on the B-BBEE Scorecard (DTI, 2008). Furthermore, the manual was to outline the responsibilities of the verification agency to its client in respect of quality control and also set the requirements based on the key measurement principles and calculations of B-BBEE policy (DTI, 2008).

An auditing model was adopted as a framework for the B-BBEE verification process (Jack, 2007). Verification is defined as the confirmation through the provision of objective evidence that specified requirements have been fulfilled (Haeckel \& Püntmann, 2001). In the context of B-BBEE, verification means the process and activities conducted by a verification agency to assess, verify and validate that the score awarded to a measured entity is a result of individual scorecard elements supplied by a measured entity and to evaluate B-BBEE transactions in order to provide an indicative B-BBEE score and certification based on the principles of the B-BBEE Codes (DTI, 2008). For the past few years, there has been a growing emphasis within the verification industry of the need to develop and improve the performance of B-BBEE verification practitioners in order to meet the increasing demands placed on the industry by both its clients and government (EconoBEE, 2011). Marais (2012) pointed to the need to enhance the competence of the industry. Developing and improving the performance of the verification industry would require of the industry and government to develop competencies of the practitioners. Table 1 identifies some of the key role players in the verification process.

TABLE 1: Key role players in the verification process

\begin{tabular}{|c|c|}
\hline Role player & Role and responsibility \\
\hline Accreditation body (South African National Accreditation System) & $\begin{array}{l}\text { Accredits verification agencies to perform verification assessments, evaluations for measured entities and issue } \\
\text { B-BBEE certificates. The accreditation body is also responsible for ensuring the consistency and quality of the } \\
\text { verification process. }\end{array}$ \\
\hline Association of BEE Verification Agencies & $\begin{array}{l}\text { Promotes the objectives of the B-BBEE Act and the Codes, high levels of professionalism and competence and } \\
\text { represent the BEE verification sector in its dealings with the DTI, South African National Accreditation System, } \\
\text { the public and other relevant stakeholders. }\end{array}$ \\
\hline Independent Regulatory Board of Auditors & $\begin{array}{l}\text { Approves registered auditors to provide B-BBEE assurance services and to issue valid B-BBEE status-level } \\
\text { certificates - referred to as B-BBEE verification certificates, to measured entities. }\end{array}$ \\
\hline B-BBEE-approved registered auditors & $\begin{array}{l}\text { Only approved Registered Auditors are responsible for assessing, verifying and issuing B-BBEE verification } \\
\text { certificates to a measured entity. }\end{array}$ \\
\hline
\end{tabular}

B-BBEE, Broad-Based Black Economic Empowerment; DTI, Department of Trade and Industry. 
The B-BBEE-approved registered auditor provides a limited assurance that, based on the work performed, the scores determined for the measured entity's B-BBEE Scorecard and the resultant B-BBEE status of the measured entity are not materially misstated (Independent Regulatory Board of Auditors [IRBA], 2012). The South African Standard on Assurance Engagements (SASAE) 3502 Assurance Engagement on B-BBEE verification certificates and the ISAE 3000 require that both assurance standards and guidance for B-BBEE verification by all approved registered auditors and professional accountant harmonise with the fundamental principles of auditing in terms of the International Ethics Standards Board for Accountants (IESBA) Code. These principles include integrity, objectivity, professional competence, due care, confidentiality and professional behaviour. Furthermore, other pronouncements of the International Auditing and Assurance Standards Board set out International Standard on Quality Control (ISQC) to deal with a firm's responsibilities for its system of quality control for audit and reviews of financial statements and related service engagements (ISQC, 2012). Because B-BBEE verification is considered as a related service engagement, it should be read in conjunction with ISQC (IRBA, 2012).

\section{Literature review and hypotheses development} Managerial competencies

According to Armstrong (2001), a competence is a workrelated concept that defines the areas of work in which a person needs to be competent. It is also described as a general description of the underlying knowledge, skills and attributes that people need to deliver worthy job performance (Stevens, 2013). Steward and Brown (2009:134) define competencies as 'traits and abilities that people need to achieve success in professional tasks'. A competency is also described as a composite of the knowledge, skills and attributes that lead to worthy job performance (Brits \& Veldsman, 2014). Competencies capture the range of procedures, skills and abilities, attitudes, beliefs and values, dispositions and personal characteristics, self-perceptions and motivations that enable a range of work demands to be met effectively (Rubin et al., 2007). Competencies should take into consideration not only job descriptions but also best practices and recent trends in the industry as well as the organisation's own strategy (Martone, 2003). Thus, a competency framework should consist of a set of 'generic' competency areas, with each competency area to be composed of a limited number of competencies that would be relevant, to different degrees for every concerned job position (Lucia \& Lepsinger, 1999). Furthermore, research by Mansfield (1999) shows that a competency relates to characteristics that result in effective performance. These are variously defined in terms of those essential personal traits, skills, knowledge and motives of the employee that are related to superior performance (Dainty, Cheng \& Moore, 2003). Thus, competencies can be seen as sets of related behaviours or the required knowledge, skill and ability to perform a task or role.
If managers have a certain set of competencies, then they will be successful in enhancing organisational performance (Mohd-Shamsudin \& Chuttipattana, 2012). Whilst scholars have categorised competencies into different groups (Mohd-Shamsudin \& Chuttipattana, 2012), the aim of the present study is concerned with the identification of critical managerial competencies and how they relate to perceived job performance for B-BBEE verification practitioners. Several typologies of managerial competencies have been studied over time. For example, Katz (1974) identified three types of skills, technical, human and conceptual, indicating that the latter is the most critical for top leaders. Christensen, Andrews and Bower (1978) proposed a typology of managerial skills with respect to types of leadership according to which taskmasters, mediators, motivators and leaders should possess human, sensitivity and administrative ability; personal leaders need to hold persuasion and articulation skills; and architect leaders need creativity skills, intellectual ability and conceptual ability (Carmeli \& Tishler, 2006). The studies by Castanias and Helfat (1991) and Bailey and Helfat (2003) determined the following four types of skills constituting managerial competency: (1) generic skills, which are transferable across sectors and organisations; (2) sector-related skills; (3) organisation-specific skills and (4) 'industry-related' skills. Scullen, Mount and Judge (2003) identified the following dimensions of managerial competence: (1) technical skill; (2) administrative skill; (3) human skill and (4) citizenship behaviour. This study has adopted Scullen et al. (2003) typology of managerial competencies and seeks to determine the relative importance of these to the job performance of B-BBEE verification practitioners.

Administrative skill subsumes areas such as planning, organising, delegating and coordinating. It overlaps with managerial skill in this study. Human skill is concerned with a manager's ability to interact and work effectively with team members. In this study, human skill overlaps with interpersonal skill. Finally, citizenship behaviour is referred to as upholding standards and ethics. Because there are no existing managerial competencies for B-BBEE verification practitioners, the competency list that contains items established by Internal Auditor Competency Framework (IACF) (2010) was deemed to be the closest for the purposes of this study and the items were accordingly used. The IACF competency list includes technical skills, interpersonal skills, management skills and the upholding of standards and ethics - dimensions similar to those identified by Scullen et al. (2003) as stated above. However, to make sure that the competency list was applicable to the context of the study, it was verified by three senior B-BBEE verification practitioners deemed to be best qualified to determine baseline competencies for the B-BBEE verification practitioners.

\section{Technical skills and perceived job performance}

According to Yukl (2002), technical skills include knowledge about methods, processes and equipment for conducting 
the specialised activities of the managers' organisational unit. Technical skills also include factual knowledge about organisation (rules, structure, management systems and employee characteristics), and knowledge about the organisation's products and services (technical specifications, strengths and limitations). This type of knowledge is acquired by a combination of formal education, training and job experience. Technical skill refers to a manager's proficiency in specific methods or techniques related to that manager's functional area (Tonidandel, Braddy \& Fleenor, 2012). Hysong (2008) conceded that the relationship between technical skill and managerial performance is neither simple nor direct. Technical skills are critical for first-tier managers, serving several important functions such as communicating effectively with subordinates, verifying the soundness of the decisions they make and making programme-level decisions based on subordinates' suggestions (Badawy, 1995; Hysong, 2008). Hysong (2008) found that technical skill did not significantly increase managerial skill's predictive power. Yet, technical skill was found to be predictive of subordinate perceptions of managerial performance, over and above managerial skills' non-significant contribution. That said, this study hypothesises that:

- Hypothesis 1: There is a positive and significant relationship between the technical skills possessed by the B-BBEE verification practitioners and their perceived job performance.

\section{Interpersonal skills and perceived job performance}

Interpersonal skills (also called 'social skills') include knowledge about human behaviour and group processes, ability to understand the feelings, attitudes and motives of others and the ability to communicate clearly and persuasively (Yukl, 2002). Interpersonal skills such as empathy, social insight, charm, tact and diplomacy, persuasiveness and oral communication ability are essential to develop and maintain cooperative relationships with subordinates, superiors, peers and outsiders (Northouse, 2004). These skills are concerned with a manager's ability to interact and work effectively with team members (Tonidandel et al., 2012). Interpersonal skills concern communicating supportively, gaining power and influence, managing conflict and motivating employees (McKenna, 2004). These skills also include the ability to lead, delegate, communicate, negotiate, develop people and manage conflict (Al-Madhoun \& Analoui, 2002). Recent work, however, suggests that not only is a theory of interpersonal relationships lacking, but that interpersonal skills training for managers has a negligible impact overall (Hunt \& Baruch, 2003). A study by Bambacas and Patrickson (2008) demonstrated that some good interpersonal skills on the part of the managers are considered to be important in enhancing employee commitment, whilst Al-Madhoun and Analoui (2002) found that interpersonal skills constitute the most important category for the increased effectiveness of managers, irrespective of their position within the organisation. In part, the present study seeks to find a relationship between self-reported interpersonal skills and job performance. In light of this, the following hypothesis is postulated:

- Hypothesis 2: There is a positive and significant relationship between the interpersonal skills possessed by the B-BBEE verification practitioners and their perceived job performance.

\section{Managerial skills and perceived job performance}

Management skills consist of 'identifiable sets of actions that individuals perform and that lead to certain outcomes' (McKenna, 2004:665; Whetten \& Cameron, 2002). Managerial skills are not universal phenomena able to be defined and measured in a clear and objective way. Instead, these skills are particularistic, situated, contextual, and socially constructed (Billsberry \& Birnik, 2010; Chia, 1996; McKenna, 2004). Bergenhenegouwen (1996) argued that in a managerial context, managers must possess a range of competencies to perform effectively. In this regard, Cheng, Dainty and Moore (2005) hold that performance management is a core strategic human resources management activity to which competence and competency frameworks can be applied. More recently, a study by Tonidandel et al. (2012) found that overall managerial capability was the most important predictor of a manager's effectiveness. Carmeli and Tishler (2006) concede that even though there is agreement about the multi-dimensional nature of performance, there remains little empirical work relating managerial skills to such performance measures. Furthermore, De Waal, Van der Heijden, Selvarajah and Meyer (2011) believe there is a need for academically grounded leadership research into the effectiveness characteristics of managers. Hence, the following hypothesis is postulated:

- Hypothesis 3: There is a positive and significant relationship between the management skills possessed by the B-BBEE verification practitioners and their perceived job performance.

\section{Compliance to standards and ethics and perceived job performance}

Ethical sensitivity is the ability to identify and recognise ethical issues when they arise and moral reasoning judgement relate to how and why ethical decisions are made (Jackling, Cooper, Leung \& Dellaportas, 2007). Sullivan (2004) conceptualised knowledge of ethics as members' knowledge of a set of ethical principles and statements issued by the professional body to regulate its members. He further states that as professionals, auditors are expected to have sufficient knowledge of ethics and understand what the codes of ethical standards comprise. According to Zakaria, Haron and Ismail (2010), the purpose of the code is to enhance members' knowledge and guide them in recognising ethical problems and thus formulating ethical judgement. The codes of ethics are designed to ensure that the ethics of the professional group are the ethics internalised by the individual practitioner. Codes mitigate against individuals applying the expertise of the profession to ends that are not the ends deemed good by the professional body (Williams, 2010). As professionals, 
auditors are expected to have sufficient knowledge of ethics and to understand what the codes of ethical standards comprise. The underlying reason is that the accounting professional body requires the auditors to apply similar standards in which ethical judgements are laid down in the profession's ethical code (Zakaria et al., 2010). In fact, prior research has found that auditors with higher levels of moral development rely more on judgement and less on technical standards for problem resolution (Sweeney \& Roberts, 1997). According to Jackling et al. (2007), the problem for professionals is that ethical issues are often hidden and they often lack the ethical sensitivity to recognise ethical dilemmas when they arise. A study by Okpara and Wynn (2007) found that favourable organisational ethical climates encourage commitment and job satisfaction:

- Hypothesis 4: There is a positive and significant relationship between compliance to standards and ethics by the B-BBEE verification practitioners and their perceived job performance.

\section{Research method \\ Design, sampling and data collection}

A quantitative design using the survey approach was adopted for the present study. The survey method was deemed appropriate for the study because it enables data collection from large populations, making it easier to develop and administer the research questionnaire whilst allowing for generalisation of the research findings (Malhotra, 2010). A total of 200 questionnaires were distributed to the verification practitioners employed by a full population of 80 verification agencies in South Africa. Of these questionnaires, 87 were completed and deemed usable for further processing, thereby yielding a response rate of $43.5 \%$. Similar studies (Awad \& Alhashemi, 2012; Shetach \& Marcus, 2013) were based on samples of 85,104 and 107 respondents. A list of all verification agencies was obtained from the South African National Accreditation System website. Each survey was accompanied by a cover letter that explained the purpose of the study and also ensured confidentiality of participants' responses and their right to anonymity. Respondents were reminded of their voluntary participation and that they reserve the right to withdraw from the study at any stage, should they so wish. This was underscored especially considering an inherent risk of common source bias in self-reports. Yet, self-reports were clearly the most appropriate considering the aim of the study. In this regard, Conway and Lance (2010) concur that whilst other types of measures might be appropriate or even superior, self-reports are appropriate for job satisfaction and many other private events. Another argument for using selfreports was advanced by Shalley, Gilson and Blum (2009), who argued that in certain cases, employees are best suited to self-report because they are the ones who are aware of the subtle things they do or need in their jobs. Thus, in the present study self-reports were deemed appropriate because it was about professionals identifying the relative importance of their managerial competencies in the enhancement of their own perceived job performance.

\section{Measuring instrument}

Because there are no existing managerial competencies for $\mathrm{B}-\mathrm{BBEE}$ verification practitioners, the competency list that contains questionnaire items established by IACF (2010) was used to measure managerial competency. However, to make sure that the competency list was applicable to the context of the study, it was verified by three senior B-BBEE verification practitioners deemed to be best qualified to determine baseline competencies for the B-BBEE verification practitioners. Section A determined the demographic profile of the participants. Sections B to E were adapted from the IACF (2010) questionnaire, which contained questions on technical skills, interpersonal skills, management skills and standards and ethics. Section F contained items to measure job performance that were adapted from Chiang and Hsieh (2011). All items were scored such that a higher score indicated higher standing on the construct being measured. A 5-point Likert scale was used, where $1=$ strongly disagree and $5=$ strongly agree.

\section{Results}

Data were analysed using the Statistical Package for the Social Sciences (version 22.0) and Smart Partial Least Squares software. Demographic data of the subjects, frequencies and the scores of the factors as well as measures of central tendency were established. Internal consistency estimates were formulated using Cronbach's alpha coefficients. Further statistical procedures that include the Pearson correlation analysis and linear regression analysis were used as bases for testing the hypotheses.

\section{Sample composition}

Table 2 presents the sample profile characteristics.

The data indicate that $13.8 \%$ of respondents were people aged from 20 to 25 years, $35.6 \%$ were aged between 26 and 35 years, another $35.6 \%$ were respondents aged between 36 and 45 years, $13.8 \%$ were aged between 46 and 55 years and $1.1 \%$ were 56 years and above. The number of female respondents (54\%) exceeds their male counterparts (46\%).

Table 3 presents the professional profile of the respondents.

Table 3 shows that $66.7 \%(27.6 \%+39.1 \%)$ of respondents, representing the majority, hold either a degree or a postgraduate academic qualification, with most in possession of the latter qualification. Nearly half $[49.4 \%(35.6+13.8)]$ of the respondents function at a managerial level, whilst the other half function at the technical $(21.8 \%)$ and verification analyst $(27.6 \%)$ levels. The sample seems to represent the population of the verification practitioners.

\section{Reliability and validity of the instrument}

The reliability of the measuring instrument was assessed, and Table 4 reflects the results for each variable. The Cronbach's alpha coefficient of at least 0.7 confirms the reliability of the instrument in effectively capturing the 
variables examined in the study (Chin, 1998). Content and face validity of the instrument were ascertained through the review by three senior B-BBEE verification practitioners deemed to be best qualified to determine baseline competencies for the B-BBEE verification practitioners. Their feedback ensured that the instrument only comprised those questions that would validly capture the aims of the study. Convergent validity of the measurement scale was assessed in two ways. Firstly, the high Cronbach's alpha coefficients, ranging from 0.946 and $0.989(\geq 0.70)$ reflect the degree of cohesiveness of the items contained within the variable measures, thereby serving as an indirect indicator of convergent validity (Nunnally \& Bernstein, 1994). Secondly, Pearson correlation coefficients indicate the high degree of convergence amongst the constructs linked in the conceptual model. The model provides relatively poor evidence of discriminant validity as a result of fairly high intercorrelation factors. In this regard, Tabachnick and Fidell (2013) caution that a factor correlation that equals or exceeds 0.85 is often used as the cut-off criterion for problematic discriminant validity.

TABLE 2: Sample profile characteristics.

\begin{tabular}{lccc}
\hline Characteristic & Description & Frequency & $\mathbf{\%}$ \\
\hline Gender & Male respondents & 40 & 46 \\
& Female respondents & 47 & 54 \\
Total & - & 87 & 100 \\
Age & $20-25$ & 12 & 13.8 \\
& $26-35$ & 31 & 35.6 \\
& $36-45$ & 31 & 35.6 \\
& $46-55$ & 12 & 13.8 \\
& $56+$ & 1 & 1.1 \\
\hline Total & - & $\mathbf{8 7}$ & $\mathbf{1 0 0}$ \\
\hline
\end{tabular}

TABLE 3: Professional profile of the respondents.

\begin{tabular}{llcc}
\hline Characteristic & Description & Frequency & $\mathbf{\%}$ \\
\hline Academic qualification & Matriculation & 13 & 14.9 \\
& Certificate & 1 & 1.1 \\
& Diploma & 13 & 14.9 \\
& Degree & 24 & 27.6 \\
& Postgraduate degree & 34 & 39.1 \\
& Other & 2 & 2.3 \\
Professional background & Legal & 8 & 9.2 \\
& Accounting and finance & 17 & 19.5 \\
& Consulting & 7 & 8.0 \\
& Auditing & 15 & 17.2 \\
& Supply chain and procurement & 9 & 10.3 \\
& Other & 31 & 35.6 \\
Job title & Owner & 12 & 13.8 \\
& Manager & 31 & 35.6 \\
& Technical signatory & 19 & 21.8 \\
& Verification analyst & 24 & 27.6 \\
\hline
\end{tabular}

According to Farrell (2010), whenever there are high construct inter-correlations, there is a need to assess discriminant validity, in order to have confidence in subsequent research findings. In this regard, the technique proposed by Fornell and Larcker (1981) to assess discriminant validity was used. According to Fornell and Larcker (1981), for any two constructs A and B, the average variance extracted (AVE) for A and the AVE for B both need to be larger than the shared variance (i.e. square of the correlation) between A and B. That is, both AVE estimates have to be greater than the shared variance estimate. Hair, Jr., Black, Babin, Anderson and Tatham (2006, p. 778) support using this technique for assessing discriminant validity and accordingly note that 'the variance extracted estimates should be greater than the squared correlation estimate'. At the same time, the factors should have an AVE of more than 0.5 (Chin, 1998). It can be seen from Tables 4 and 5 that the values for AVE all exceed 0.5 and are all greater than their respective shared variance estimates, thereby confirming the existence of discriminant validity of the measurement used in this study.

\section{Correlation and regression analyses}

Pearson correlations were computed with a view to ascertain relationships between the independent variables, namely, technical skills, interpersonal skills, management skills and compliance to standards and ethics on the one hand and the dependent variable, namely perceived job performance, on the other. Table 4 reports on the correlation results between the variables.

As can be seen from Table 4, the relationship between the management competencies (technical, interpersonal, standards and ethics as well as managerial skills) and perceived job performance show significant positive correlations. A strong positive association was observed between technical skills and perceived job performance $(r=0.621 ; p<0.05)$. A positive and strong association was found between interpersonal and perceived job performance $(r=0.830 ; p<0.05)$. Regarding managerial skills, a positive and strong association $(r=0.809$; $p<0.01)$ was also observed between managerial skills and perceived job performance. A positive and strong association was observed between compliance to standards and ethics and perceived job performance $(r=0.801 ; p<0.05)$.

The next step was to determine the extent to which these variables predict perceived job performance. To this end, multiple regression analysis was computed. Table 6 presents the regression model summary results.

Table 6 provides the $R$ and $R^{2}$ values. The $R$ value of 0.897 indicates a high degree of correlation, whilst the $R^{2}$ or adjusted $R^{2}$ value indicates how much of the total variation in

TABLE 4: Inter-construct correlations.

\begin{tabular}{|c|c|c|c|c|c|c|}
\hline Research constructs & Shared variance (square of $R$ ) & PJP & TS & IS & SE & MS \\
\hline Perceived job performance & 1 & 1 & - & - & - & - \\
\hline Technical skills & 0.386 & 0.621 & 1 & - & - & - \\
\hline Interpersonal skills & 0.689 & 0.83 & 0.775 & 1 & - & - \\
\hline Standard and ethics & 0.642 & 0.801 & 0.823 & 0.851 & 1 & - \\
\hline Management skills & 0.654 & 0.809 & 0.596 & 0.837 & 0.759 & 1 \\
\hline
\end{tabular}

PJP, perceived job performance; TS, technical skills; IS, interpersonal skills; SE, standards and ethics; MS, management skills. 
TABLE 5: Accuracy of analysis statistics.

\begin{tabular}{|c|c|c|c|c|c|c|c|}
\hline \multicolumn{2}{|c|}{ Research variable } & \multirow{2}{*}{$\frac{\text { Mean }}{4.327}$} & \multirow{2}{*}{$\frac{R^{2} \text { value }}{0.588}$} & \multirow{2}{*}{$\frac{\text { Cronbach's alpha value }}{0.969}$} & \multirow{2}{*}{$\frac{\text { CR value }}{0.976}$} & \multirow{2}{*}{$\frac{\text { AVE value }}{0.890}$} & \multirow{2}{*}{$\begin{array}{c}\text { Factor loading } \\
0.955\end{array}$} \\
\hline IS & IS1 & & & & & & \\
\hline & IS2 & & & & & & 0.933 \\
\hline & IS3 & & & & & & 0.971 \\
\hline & IS4 & & & & & & 0.959 \\
\hline & IS5 & & & & & & 0.898 \\
\hline \multirow[t]{6}{*}{ SE } & SE1 & 4.322 & 0.789 & 0.951 & 0.963 & 0.815 & 0.947 \\
\hline & SE2 & & & & & & 0.972 \\
\hline & SE3 & & & & & & 0.979 \\
\hline & SE4 & & & & & & 0.959 \\
\hline & SE5 & & & & & & 0.629 \\
\hline & SE6 & & & & & & 0.885 \\
\hline \multirow[t]{8}{*}{ TS } & TS1 & 4.370 & 0.783 & 0.989 & 0.991 & 0.931 & 0.952 \\
\hline & TS2 & & & & & & 0.980 \\
\hline & TS3 & & & & & & 0.951 \\
\hline & TS4 & & & & & & 0.984 \\
\hline & TS5 & & & & & & 0.980 \\
\hline & TS6 & & & & & & 0.939 \\
\hline & TS7 & & & & & & 0.968 \\
\hline & TS8 & & & & & & 0.966 \\
\hline \multirow[t]{5}{*}{ MS } & MS1 & 4.286 & 0.701 & 0.963 & 0.972 & 0.873 & 0.947 \\
\hline & MS2 & & & & & & 0.932 \\
\hline & MS3 & & & & & & 0.877 \\
\hline & MS4 & & & & & & 0.959 \\
\hline & MS5 & & & & & & 0.954 \\
\hline \multirow[t]{6}{*}{ PJP } & JP1 & 4.275 & 0.791 & 0.964 & 0.971 & 0.846 & 0.843 \\
\hline & $\mathrm{JP2}$ & & & & & & 0.944 \\
\hline & JP3 & & & & & & 0.919 \\
\hline & JP4 & & & & & & 0.954 \\
\hline & JP5 & & & & & & 0.921 \\
\hline & JP6 & & & & & & 0.937 \\
\hline
\end{tabular}

IS, interpersonal skills; SE, standards and ethics; TS, technical skills; MS, management skills; PJP, perceived job performance; CR, composite reliability; AVE, average variance reliability.

TABLE 6: Regression model summary results.

\begin{tabular}{lcccc}
\hline Model & $\boldsymbol{R}$ & $\boldsymbol{R}^{\mathbf{2}}$ & Adjusted $\boldsymbol{R}^{\mathbf{2}}$ & Standard error of the estimate \\
\hline 1 & $0.897^{\mathrm{a}}$ & 0.804 & 0.794 & 0.28812 \\
\hline
\end{tabular}

Dependent variable: perceived job performance. Predictors (constants): management skills, technical skills, standards and ethics and interpersonal skills.

a, Predictors (constants): management skills, technical skills, standards and ethics and interpersonal skills.

the dependent variable, perceived job performance, can be explained by the independent variables (technical skills, interpersonal skills, standards and ethics, and managerial skills). The adjusted $R^{2}$ is a modified version of $R^{2}$ that has been adjusted for the number of predictors in the model (Frost, 2013). In this case, $79.4 \%$ of the perceived job performance of the B-BBEE verification practitioners can be explained by the management competencies, which is very large. The other $20.6 \%$ of variability of job performance can be explained by other factors not explored in this study.

Table 7 is the analysis of variance table, which reports how well the regression equation fits the data (i.e. predicts the dependent variable).

Table 7 shows that the regression model is statistically significant at $p=0.000(p<0.001)$. This indicates that, overall, the model applied can statistically significantly predict the dependent variable, namely perceived job performance, thereby indicating that the data are suitable for the next step, namely, regression analysis.
TABLE 7: Analysis of variance.

\begin{tabular}{lccccc}
\hline Model & Sum of squares & $\boldsymbol{d} \boldsymbol{f}$ & Mean squares & $\boldsymbol{F}$ & Significance \\
\hline Regression & 27.905 & 4 & 6.976 & & \\
Residual & 6.807 & 82 & 0.083 & 84.038 & $0.000^{\mathrm{b}}$ \\
\hline Total & $\mathbf{3 4 . 7 1 3}$ & $\mathbf{8 6}$ & - & - & - \\
\hline
\end{tabular}

Dependent variable: perceived job performance. Predictors (constants): management skills, technical skills, standards and ethics and interpersonal skills.

$d f$, degrees of freedom; $F$, variance of the group means.

b, The regression model is statistically significant at $p=0.000(p<0.001)$.

Table 8 provides the necessary information to predict perceived job performance from managerial competencies (technical skills, interpersonal skills, standards and ethics, and managerial skills) as well as determine whether independent variables and managerial competencies contribute statistically significantly to the model.

An important assumption of proceeding with multiple regression analysis is to ensure that there is no multicollinearity, a situation in which the predictor variables correlate too highly $(r>0.9)$ with each other (Field, 2005). Yet, some of the observed correlations, including correlations corrected for reliability as per Table 4 , did not touch the 0.9 mark. That said, the data were considered suitable for regression analysis considering that it was well within the range of tolerance and the variance inflation factor (VIF), which was used to test multi-collinearity. In the present study, tolerance was between 0.167 and 0.288 . Field (2009) posits that if the VIF is greater than 10, it implies that the predictor 
TABLE 8: Regression analysis: Managerial competencies and job performance.

\begin{tabular}{lccccc}
\hline $\begin{array}{l}\text { Managerial } \\
\text { competencies }\end{array}$ & Beta & $\boldsymbol{t}$ & Significance & \multicolumn{2}{c}{ Collinearity statistics } \\
\cline { 5 - 6 } & & & & Tolerance & $\begin{array}{c}\text { Variance } \\
\text { inflation factor }\end{array}$ \\
\hline Technical skills & -0.148 & -1.621 & 0.109 & 0.288 & 3.472 \\
$\begin{array}{l}\text { Interpersonal } \\
\text { skills }\end{array}$ & 0.245 & 2.045 & 0.044 & 0.167 & 5.987 \\
$\begin{array}{l}\text { Standards and } \\
\text { ethics }\end{array}$ & 0.384 & 3.636 & 0.000 & 0.215 & 4.657 \\
$\begin{array}{l}\text { Managerial } \\
\text { skills }\end{array}$ & 0.451 & 4.863 & 0.000 & 0.278 & 3.594 \\
\hline
\end{tabular}

variables are correlated amongst themselves, which makes collinearity a cause for concern. Whilst the data in the present study have not reached these levels, the multi-collinearity is considered to be moderate. The VIF for the four subscales in the current study ranged between 3.472 and 5.987, which indicates no problem of multi-collinearity. Consequently, the 'enter' method of regression was applied to the data set with a view to ascertaining whether any correlations exist between the four managerial competencies (independent variables) and job performance (dependent variable).

Furthermore, the Beta values in Table 8 show that managerial skills is the strongest predictor of job performance $(\beta=0.451$; $t=4.863 ; p<0.05)$, followed by standards and ethics $(\beta=0.384 ; t=3.636 ; p<0.05)$ and interpersonal skills $(\beta=0.245 ; t=2.045 ; p<0.05)$. An interesting result is the negative and insignificant predictive relationship ${ }^{1}(\beta=-0.148$; $t=-1.621 ; p>0.05)$ between technical skills and perceived job performance, given that other predictors in the model are held constant.

\section{Discussion}

The purpose of the study was to determine the managerial capabilities that are required of the B-BBEE verification practitioners, in order to improve their perceived job performance. This study reveals several findings that merit further discussion. This study tested the hypotheses that technical skills, interpersonal skills, managerial skills and compliance to standards and ethics have a positive and significant influence on the perceived job performance of the B-BBEE verification practitioners. The data supported the three hypotheses.

\section{Technical skills and perceived job performance}

The finding of the negative and insignificant predictive relationship between technical skills and perceived job performance seems to be consistent with some studies, which found technical skill is unnecessary for managerial performance (Hysong, 2008). The finding is also supported by some models of management, which propose that at best, technical skill is a peripheral competency of management (Boyatzis, 1982) whilst others loosely suggest that technical skill could be a hindrance to good management (Hysong, 2008). This finding could be explained by the fact that, as

\footnotetext{
1.These Beta values should be interpreted with caution as the relatively high intercorrelations of the predictor variables result in biased estimates of the standard correlations of the predictor variables result in biase
errors in the model (Tonidandel \& LeBreton, 2011).
}

noted in Table 3, two-thirds [66.7\% $(27.6+39.1)]$ of the respondents possess degrees and postgraduate qualifications. This figure shows that more than $80 \%$ of respondents with diplomas are included, making it an industry with highly qualified technical staff at the moment. Another plausible explanation could be in line with some studies which, having observed activities performed by managers, found a low incidence of activities requiring technical expertise (Beauvais, 1992; Dunning, 1993). This is perhaps the reason why developing themselves in the technical aspects is the least of their concern.

\section{Interpersonal skills and perceived job performance}

As noted earlier, interpersonal skills emerged as a statistically significant predictor of perceived job performance in the regression analysis, albeit the least significant when compared to managerial skills and compliance to standards and ethics. These findings seem to find alignment with a study by Al-Madhoun and Analoui (2002), which found that of the three skills, namely self-rated (managerial), people skills (interpersonal skills) and task (technical skills), the majority of participants rated in this order managerial skills, interpersonal skills and technical skills as skills they wish to develop. Based on these findings, hypothesis 3 is supported.

\section{Managerial skills and perceived job performance}

As observed in the regression analysis, managerial skills emerged as the most statistically significant predictor of perceived job performance. These findings reveal that the managerial skills are the most important predictor of perceived job performance. Interestingly, of all the four competencies, the study found managerial skill to be the best predictor of perceived job performance by the B-BBEE verification practitioners. In line with these findings, a study by Carmeli and Tishler (2006) found that the ability to lead the organisation to meet its goals rests on the integration of the managerial skills and that managerial skills are positively related to firm performance. Analoui (1990) also found that senior officials who have already gained substantial knowledge and skills about the technical aspects of their job tend to place more emphasis on their own development, thus viewing institutional development as a direct consequence of their own. Furthermore, Tonidandel et al. (2012) found a 'unique contribution' made by managerial skills in managerial evaluations. Based on these findings, hypothesis 3 is supported and accepted.

\section{Standards and ethics and perceived job performance}

Compliance to the standards and ethics variable also emerged as a statistically significant predictor of perceived job performance in the regression analysis. In fact, the present study found compliance to standards and ethics is the second most important predictor of perceived job performance for the B-BBEE verification practitioners. This finding is 
noteworthy and shows how important compliance to standards and ethics are in this environment and how much the respondents feel the need for this skill in the execution of the duties. The need for the ethics education could well reflect an observation that a lack of attention has been given to the ethical and professional values of honesty, integrity, objectivity, due care and the commitment to the public interest before one's own interests (Jennings, 2004; Parker, 2005). In a study by Jackling et al. (2007), professional bodies acknowledged that ethics is capable of being taught other than in the workplace, thus supporting the idea that social and behavioural skills linked to ethics education can be learnt in educational programmes (Earley \& Kelly, 2004). Overall, the findings of this study are consistent with the expectations of ethical management theories and the ethical behaviour of managers (Okpara, 2002). The findings are also in line with previous findings in ethics studies (Deshpande, 1996; Koh \& Boo, 2001). Thus, hypothesis 4 is supported and is accepted in this study.

\section{Limitations and direction for future research}

Some limitations to the study should be noted. First, the competencies of the managers were self-reported, rather than independently assessed (or assessed by their supervisors). Whilst it has been argued that people are not always good self-assessors (Kevin \& Glenn, 2008; Kim \& Chiu, 2011), the argument was made why this was deemed appropriate for the present study. As discussed in the Research Method section, whilst every effort was made to mitigate the effects of the common source bias, it could not be ruled out completely. Another limitation of the study is a relatively small sample that was studied. Thus, the findings of the study are limited in that they are restricted to only 87 participants, who are the current cohort of the B-BBEE verification practitioners, thereby limiting the extent to which the findings can be generalised to other cohorts with different profiles. Although discriminant validity was assessed and supported, the relatively high inter-factor correlations remained a cause for concern. Future studies could consider using other more objective measures. Finally, as noted earlier, the study considered only one typology, amongst the many, of managerial competencies. Future studies could consider other typologies with a view to prioritise the skills accordingly. Furthermore, a similar study could be conducted with auditors who are performing B-BBEE verification services to determine if there are similarities or differences with the main findings from this study.

\section{Conclusion and managerial implications}

The purpose of the study was to determine the managerial capabilities that are required of the B-BBEE verification practitioners, in order to improve their perceived job performance. The results of the correlation analysis revealed that there were strong and positive associations between technical skills, interpersonal skills, compliance to standards and ethics, managerial skills and perceived job performance. Results of the regression analysis showed that managerial skills, compliance to standards and ethics and interpersonal skills were statistically significant in predicting perceived job performance. However, technical skills were insignificant in predicting perceived job performance.

These findings suggest that whilst the current cohort of verification practitioners have the necessary technical expertise to perform their tasks well, they, however, view managerial skills as the most important area of their work if they are to improve their perceived job performance. This is understandable in light of the fact that, as noted earlier, half of the respondents currently function as technical signatories and verification analysts and not as managers yet. However, many of these might already be performing some managerial functions for which they require training. It is also likely that many who are now managers were promoted into those positions on the basis of their technical competence. These are the ones who seem to feel a strong need to be developed managerially. Just after managerial skills are standards and ethics, which are also strong predictors of job performance. This is also understandable because B-BBEE is the arena for the contestation of business in the form of contracts and tenders. Thus, very likely there might be a tendency for the verification practitioners to find themselves in ethically compromising positions as a result of pressure from the companies to want to attain or maintain competitive B-BBEE ratings. Indeed, whilst the verification practitioners do not want to neglect improving their interpersonal skills, the need to enhance their skills in the areas of managerial skills and standards and ethics would be a matter of priority.

In view of the above, any training and development programme aimed at enhancing the perceived job performance of B-BBEE verification practitioners should be investigated with a view to address the competencies discussed. Managerially, the study has shown the B-BBEE verification industry, that insofar as the technical skills of the practitioners are concerned, it does have suitably qualified staff with the requisite educational qualifications. At the same time, from the present study the industry can now determine the priority skills. The study identified the needed skills as managerial skills, standards and ethics and interpersonal skills, in that order. The allocation of credit for a training and development programme would also need to be in that order.

\section{Acknowledgements Competing interests}

The authors declare that they have no financial or personal relationships which may have inappropriately influenced them in writing this article.

\section{Authors' contributions}

B.M.S. collected data and contributed with some literature review and data analysis. R.I.D.P. was responsible for the literature review, article write-up and some data analysis and R.C. made some data analysis contributions. 


\section{References}

Al-Madhoun, M., \& Analoui, F. (2002). Developing managerial skills in Palestine Education and Training, 4 (8/9), 431-442.

Analoui, F. (1990). Managerial skills for senior managers. International Journal of Public Sector Management, 3(2), 26-38.

Armstrong, M. (2001). A handbook of human resource management practice. London: Kogan Page.

Awad, T.A., \& Alhashemi, S.E. (2012). Assessing the effect of interpersonal communications on employees' commitment and satisfaction. International Journal of Islamic and Middle Eastern Finance and Management, 5(2), 134-156.

Badawy, M.K. (1995). Developing managerial skills in engineers and scientists: Succeeding as a technical manager, (2nd ed.). New York, NY: Van Nostrand Reinhold.

Bailey, E.E., \& Helfat, C.E. (2003). External management succession, human capital and firm performance: An integrative analysis. Managerial and Decision Economics, 24(4), 347-369.

Bambacas, M., \& Patrickson, M. (2008). Interpersonal communication skills that enhance organizational commitment. Journal of Communication Management $12,51-72$.

Beauvais, L.L. (1992). The effects of perceived pressures on managerial and nonmanagerial scientists and engineers. Journal of Business and Psychology, 6(3) managerial.

Bergenhenegouwen, G.J. (1996). Competence development - A challenge for HRM professionals: Core competences of organizations as guidelines for the development of employees. Journal of European Industrial Training, 20(9), 29-35.

Billsberry, J., \& Birnik, A. (2010). Management as a contextual practice: The need to blend science, skills and practical wisdom. Organization Management Journal, 7, 171-178.

Boyatzis, R.E. (1982). The competent manager: A model for effective performance. New York: John Wiley \& Sons.

Brits, D.W., \& Veldsman, T.H. (2014). A global central banker competency model. SA Journal of Human Resource Management, 12(1), 1-14.

Business Report. (2008). BEE progress shocking. Editor. Keith Ross, 24 August.

Carmeli, A., \& Tishler, A. (2006). The relative importance of the top management team's managerial skills. International Journal of Manpower, 27(1), 9-36.

Castanias, R.P., \& Helfat, C.E. (1991). Managerial resources and rents. Journal of Management, 17(1), 155-71.

Cheng, M., Dainty, A.R.J., \& Moore, D.R. (2005). What makes a good project manager? Human Resource Management Journal, 15(1), 25-37.

Chia, R. (1996). Organizational analysis as deconstructive practice. Berlin and New York: Walter de Gruter

Chiang, C.F., \& Hsieh, T.S. (2011). The impacts of perceived organizational support and psychological empowerment on job performance: The mediating effects of organizational citizenship behaviour. International Journal of Hospitality Management, 31(1), 180-190.

Chin, W.W. (1998). Issues and opinion on structural equation modelling. MIS Quarterly, 22(1), 7-16

Christensen, C.R., Andrews, K.R., \& Bower, J.L. (1978). Business policy: Test and cases, 4th (ed.). Homewood, IL: Richard D. Irwin, Inc.

Conway, J.M., \& Lance, C.E. (2010). What reviewers should expect from author regarding common method bias in organizational research. Journal of Business Psychology, 25, 325-334.

Dainty, A.R.J., Cheng, M.I., \& Moore, D.R. (2003). Redefining performance measures for construction project managers: An empirical evaluation. Construction Management and Economics, 21(2), 209-218.

Department of Trade and Industry (DTI). (2007). Broad-Based Black Economic Empowerment Codes of good practice. Pretoria: Government Printers.

Department of Trade and Industry (DTI). (2008). Verification of and reporting on Broad-Based Black Economic Empowerment Framework in terms of the Codes of Good Practice Verification Manual. Pretoria: Government Printers.

Deshpande, S.P. (1996). The impact of ethical climate types on facets of job satisfaction. Journal of Business Ethics, 15, 655-60.

De Waal, A.A., Van der Heijden, B.I.J.M., Selvarajah, C., \& Meyer, D. (2011) Characteristics of high performing managers in The Netherlands. Leadership \& Organization Development Journal, 33(2), 131-148.

Dunning, T. (1993). Accurate methods for the statistics of surprise and coincidence. Computational Linguistics, 19, 61-74.

Earley, C.E., \& Kelly, P. (2004). A note on ethics educational interventions in an undergraduate auditing course: Is there an 'Enron effect'? Issues in Accounting undergraduate auditing
Education, 19(1), 53-62.

EconoBEE. (2009). Gain a competitive edge. Retrieved 21 May, 2013, from http:// www.econobee.co.za/bee-articles-and-information/econobee-newsletters/

EconoBEE. (2011). Verification capacity slows compliance. Retrieved 15 November 2012, from http://www.econobee.co.za/bee-articles-and-information/ecobeenewsletters/

Ernest \& Young. (2013). Broad-based Black Economic Empowerment. Retrieved 09 November, 2015, from www.ey.com/publication/vwLUAssests/Boroad-based

Farrell, A.M. (2010). Insufficient discriminant validity: A comment on Bove, Pervan, Beatty and Shiu (2009). Journal of Business Research, 63, 324-327.
Field, A. (2005). Discovering statistics using SPSS. London, UK: Sage Publishers.

Field, A. (2009). Discovering statistics using SPSS. (2nd Edn.). London, UK: Sage Publishers.

Fornell, C., \& Larcker, D.F. (1981). Evaluating structural equation models with unobservable variables and measurement error. Journal of Marketing Research, 18(1), 39-50.

Frost, J. (2013). Multiple regression analysis: Use adjusted R-squared and predicted $R$-squared to include the correct number of variables. Retrieved 13 August, 2015, from http://blog.minitab.com/

Gentry, W.A., Harris, L.S., Baker, B.A., \& Leslie, J.B. (2007). Managerial skills: What has changed since the late 1980s? Leadership \& Organization Development Journal, 29(2), 167-181.

Gomez, E.T., \& Premdas, R. (2013). Affirmative action, ethnicity, and conflict. London and New York: Routledge.

Haeckel, R., \& Püntmann, I. (2001). Validation of measurement procedures, In Vitro Veritas [Online] Retrieved 17 April, 2013, from http://www.acclc.es/invitroveritas/ vol2/art20.html

Hair, Jr., J.F., Black, W.C., Babin, B.J., Anderson, R.E., \& Tatham, R.L. (2006). Multivariate data analysis (6th Ed.). New Jersey: Pearson-Prentice Hall.

Homer, M. (2001). Skills and competency management. Industrial and commercia training, 33 (2), 59-62.

Hunt, J., \& Baruch, Y. (2003). Developing top managers: The impact of interpersonal skills training. Journal of Management Development, 22(8), 729-752.

Hysong, S.J. (2008). The role of technical skill in perceptions of managerial performance. Journal of Management Development, 27(3), 275-290.

Independent Regulatory Board of Auditors (IRBA). (2012). South African Standards on Assurance Engagement (SASAE) 3502. Retrieved 09 April, 2013, from http://www. irba.co.za/index.php/b-bbee-verification-assurance

Internal Auditor Competency Framework (IACF). (2010). Sydney, Australia: Institute of Internal Auditors.

International Standard on Quality Control (ISQC). (2012). Retrieved 02 May, 2013, from http://www.ifac.org/sites/default/files/publications/files/SMP-TipsOnApplying SQC1Article-July.pdf

Jack, N. (2007). Broad-based BEE: The complete guide. Northcliff: Frontrunner Publishing.

Jackling, B., Cooper, B.J., Leung, P., \& Dellaportas, S. (2007). Professional accounting bodies perceptions of ethical issues, causes of ethical failure and ethics education. Managerial Auditing Journal, 22(9), 928-944.

Jennings, M.M. (2004). Incorporating ethics and professionalism into accounting education and research: A discussion of the voids and advocacy for training in seminal works in business ethics. Issues in Accounting Education, 19(1), 7-26.

Katz, R.L. (1974). Skills of an effective administrator. Harvard Business Review, 52(5), 90-102.

Kevin, W.E., \& Glenn, R. (2008). 'I'll never play professional football' and other fallacies of self-assessment. Journal of Continuing Education in the Health Professions, 28(1), 14-19.

Kim, Y., \& Chiu, C. (2011). Emotional costs of inaccurate self-assessments: Both selfeffacement and self-enhancement can lead to dejection. American Psychological Association, 11(5), 1096-1104.

Koh, H.C., \& Boo, E.H. (2001). The link between organizational ethics and job satisfaction: A study of managers in Singapore. Journal of Business Ethics, 29, 309-324.

Levin, R.M. (2011). Broad-based empowerment or dependent accumulation? The state and development in South Africa. In D. Plaatjies (ed.). Future inheritance Building state capacity in democratic South Africa, (pp. 162-183). Auckland Park: Jacan Media (Pty) Ltd.

Lucia, A.D., \& Lepsinger, R. (1999). The art and science of competency models Pinpointing critical success factors in organizations. San Francisco: Jossey-Bass/ Pfieffer.

Malhotra, N.K. (2010). Marketing research: An applied orientation. Eaglewood Cliffs, $\mathrm{NJ}$ : Prentice-Hall.

Mansfield, R. S. (1999). What is 'competence' all about? Competency, 6(3), 24-28.

Marais, P. (2012). B-BBEE (On-line). Retrieved November 16, 2012, from http:www. $\mathrm{fm} . c 0 . z \mathrm{z} / \mathrm{fm} / 2012 / 05 / 03 /$ bbbee-yessiree?

Martone, D. (2003). A guide to developing a competency-based performancemanagement system. Employee Relations Today, 30 (3) 23-32.

McKenna, S. (2004). Predispositions and context in the development of manageria skills. Journal of Management Development, 23 (7), 664-677.

Mohd-Shamsudin, F. \& Chuttipattana, N. (2012). Determinants of manageria competencies for primary care managers in Southern Thailand. Journal of Health Organization and Management, 26(2), 258-280.

Northouse, P. (2004). Leadership: Theory and practice. (3rd Ed.). Thousand Oaks, CA: Sage.

Nunnally, J.C., \& Bernstein, I.H. (1994). Psychometric Theory. (3rd Ed.). New York:McGraw-Hill.

Okpara, J.O. (2002). The influence of ethical climate types on job satisfaction of IT managers: Implications for management practice and development in a developing economy. San Jose, CA: Paper presented at the meeting of the Academy of Business and Administrative Sciences.

Okpara, J.O., \& Wynn, P. (2007). The impact of ethical climate on job satisfaction, and commitment in Nigeria. Journal of Management Development, 27(9), 935-950. 
Parker, L.D. (2005). Corporate governance crisis down under: Post-Enron accounting education and research inertia. European Accounting Review, 14(2), 383-394.

Pooe, D. (2013). Theoretical perspectives and the implementation of the BBBEE policy framework. Mediterranean Journal of Social Sciences, 14(14), 635-642.

Rubin, N.J., Leigh, I.W. Nelson, P.D., Smith, I.L., Bebeau, M., Lichtenberg, J.W. Portnoy, S., \& Kaslow, N.J. (2007). The competency movement within psychology: An historical perspective. Professional Psychology: Research and Practice, 38(5) $17-34$.

Rubushe, M. (2009). Trade union investment schemes: A blemish on the socia movement unionism outlook of South African unions?. Unpublished master's movement unionism out
thesis, Rhodes University.

Scullen, S.E., Mount, M.K., \& Judge, T.A. (2003). Evidence of the construct validity of developmental ratings of managerial performance. Journal of Applied Psychology, 88(1), 50-66.

Shalley, C., Gilson, L., \& Blum, T. (2009). Interactive effects of growth need strength work context, and job complexity on self-reported creative performance. Academy of Management Journal, 52, 489-505.

Shetach, A., \& Marcus, O. (2013). The critical managerial capabilities of medical and nursing managers in an Israeli hospital. Evidence-based HRM: A Global Forum for Empirical Scholarship, 3(1), 81-102.

Stevens, G.W. (2013). A critical review of the science and practice of competency modeling. Human Resource Development Review, 12(86), 86-107.

Steward, G. L., \& Brown, K.G. (2009). Human Resources Management. Linking Strategy to Practice. USA: John Wiley \& Sons Inc.
Sullivan, G.R. (2004). Enhancing public trust in the accounting professional judgment rather than personal judgment in resolving accounting ethics dilemmas. Doctora dissertation, Virginia Beach, VA: Regent University.

Sweeney, J.T., \& Roberts, R.W. (1997). Cognitive moral development and auditor independence. Accounting, Organizations \& Society, 22(3/4), 337-353.

Tabachnick, B.G., \& Fidell, L.S. (2013). Using multivariate statistics, (6th Ed.). New Jersey: Pearson Education Inc.

Tonidandel, S., Braddy, P.W., \& Fleenor, J.W. (2012). Relative importance of managerial skills for predicting effectiveness. Journal of Managerial Psychology, 27(6), 636-655.

Tonidandel, S., \& LeBreton, J.M. (2011). Relative importance analysis: A useful supplement to regression analysis. Journal of Business Psychology, 26, 1-9.

Whetten, D.A., \& Cameron, K.S. (2002). Developing management skills (5th Ed.). New Jersey: Pearson-Prentice Hall.

Williams, P.F. (2010). The focus of professional ethics: Ethical professionals or ethica profession? Research on Professional Responsibility and Ethics in Accounting, $14,15-35$.

Yukl, G.A. (2002). Leadership in organizations, 5th (Ed.). Englewood Cliffs, NJ: PrenticeHall.

Zakaria, M., Haron, H.H., \& Ismail, I. (2010). Knowledge of ethics, perceived ethical problems and ethical judgments. Journal of Financial Reporting and Accounting, $8(1), 50-64$ 